\title{
Wybrane teorie przechodzenia absolwentów szkół wyższych na rynek pracy w warunkach gospodarki opartej na wiedzy*
}

\section{Selected Theories of Higher Education Graduates' Transition into the Labour Market in a Knowledge-based Economy}

\begin{abstract}
Streszczenie: Przejście absolwentów studiów wyższych w XXI wieku z etapu edukacji do zatrudnienia to złożony proces, uzależniony od wielu czynników i rodzący szereg konsekwencji społecznych, psychologicznych, ekonomicznych o niejednorodnej skali oddziaływania. Mimo dużego znaczenia tranzycja absolwencka jest w Polsce jednym ze słabiej zbadanych zagadnień, zarówno w ujęciu teoretycznym, jak i empirycznym. Kluczowymi przyczynami tego stanu jest dopiero rodząca się w koncepcji edukacji akademickiej idea optymalizacji zatrudnialności absolwentów oraz brak cyklicznych, ogólnokrajowych monitoringów diagnozujących losy zawodowe tej populacji. Podstawą do dogłębnego zbadania wchodzenia nowo promowanych absolwentów na rynek pracy jest przestudiowanie naukowych teorii, przedstawiających mechanizmy tego procesu.

W artykule przedstawiono wybrane teorie rynku pracy i wchodzenia na rynek pracy, które są szczególnie istotne w odniesieniu do absolwentów szkół wyższych i w świetle studiów literatury poświęconej tym teoriom mają kluczowe znaczenie w procesach tranzycji zachodzących w gospodarkach opartych na wiedzy.

W warunkach dużej eklektyczności pola badań procesów tranzycji istnieje potrzeba analizy teorii wchodzenia na rynek pracy, powstałych w różnych dyscyplinach naukowych, zwłaszcza w ekonomii, socjologii i psychologii. Dlatego z dorobku nauk socjologicznych i ekonomicznych skupiono się na teorii: filtra, kapitału ludzkiego, kapitału społecznego, kompetencji, konkurencji, sygnalizacyjnej (sygnałów), segmentacji. Z obszaru badań psychologicznych zaprezentowano teorie aspiracji, determinacji, kapitału psychologicznego i motywacji.

Wymienione teorie były w różnym stopniu podstawą do budowania modeli przechodzenia absolwentów studiów wyższych na rynek pracy. Wyniki badań wskazują, że teorią, która obecnie, zdaniem specjalistów z różnych dyscyplin naukowych, najpełniej charakteryzuje mechanizmy tranzycji w gospodarce opartej na wiedzy, jest teoria kompetencji.
\end{abstract}

*Praca naukowa finansowana ze środków budżetowych na naukę w latach 2010-2012 jako projekt badawczy nr N N114 076739. 
Abstract: The transition of university graduates from the stage of education to employment in the $21^{\text {st }}$ century seems to be one of the most complex and difficult processes taking place within the labour market. The uncertainty of their successful transition is increasing in several countries and regions. This process is mainly the result of the level and condition of the economy, socio-cultural differences and the education systems. The speed and character of this transition is determined by a list of factors and generates several social, psychological and economic consequences. Despite the significance of this problem, higher education graduates' transition is one of the most underexplored problems in Poland, in both theoretical and empirical sphere.

The aim of the paper is to present selected theories of the labour market/entrance into the labour market which seems especially topical and relevant for university graduates in a knowledge-based economy.

Because the process of transition is the research subject of specialists from several scientific disciplines, there is a need to analyse these theories which were created in the field of sociology, economy and psychology. From sociological and economic disciplines competence theory, human capital theory, filter theory, job-competition theory, social capital theory, signalling and segmentation theory were analysed and interpreted. From psychology the analysis focused on aspiration theory, self-determination theory, psychological capital theory, and motivation theory.

All these theories were, disproportionally, the base for building the models of university graduates transition into the labour market. The literature research proves that the theory which nowadays plays a key role in successful entrance into the labour market in a knowledge-based economy, according to specialists from different disciplines, is competence theory.

Słowa kluczowe: absolwent; rynek pracy; studia wyższe; teoria rynku pracy; tranzycja

Key words: higher education; graduate; labour market; labour market theory; transition

\section{WPROWADZENIE}

W koncepcji gospodarki opartej na wiedzy, która powstała w procesie poszukiwania nowych (obok tradycyjnych) determinant postępu, przyjęto, że wiedza stanowi jeden z najważniejszych czynników produkcji i rozwoju społeczno-gospodarczego regionów (Kabaj, 2001; Kukliński, 2001; Chojnicki, Czyż, 2003; Borowiec, 2008; Zioło, 2008). W takim ujęciu wiedza staje się podstawowym kapitałem, a edukacja najskuteczniejszym sposobem jego akumulacji. Kształcenie, zwłaszcza na szczeblu akademickim, sprzyja gromadzeniu najwyższej jakości zasobów intelektualnych, czyli kompetencji pracowników, w których tkwi źródło przewagi konkurencyjnej poszczególnych przedsiębiorstw (Makulska, 2012).

Kondycja gospodarcza regionu/kraju, wyrażona poziomem uprzemysłowienia i rozwojem sektora usług, warunkuje wielkość i strukturę popytu na zasoby pracy. Edukacja akademicka umożliwia zbudowanie cenionego przez potencjalnych pracodawców zestawu umiejętności, ucieleśnionego w każdym podmiocie zdolnym do efektywnego poszukiwania zatrudnienia, a następnie rzetelnego wypełniania zadań służbowych. Absolwenci studiów wyższych są ważnym podmiotem w zakresie podaży pracy i powinni być szczególnie atrakcyjni dla pracobiorców w różnych obszarach działalności gospodarczej. Należałoby zatem oczekiwać wysokiej efektywności inwestycji w edukację, szczególnie na poziomie akademickim, która powinna zapewniać absolwentom atrakcyjną pozycję na rynku pracy, możliwość swobodnego przemieszczania się między przedsiębiorstwami, wysokie wynagrodzenia. 
Tymczasem w Polsce i w wielu innych krajach obserwuje się rosnące trudności ze zdobyciem pracy przez osoby legitymujące się wyższym wykształceniem. Przejście absolwentów studiów wyższych w XXI wieku z etapu edukacji do zatrudnienia jest jednym z bardziej złożonych procesów zachodzących na rynku pracy. Szczególnie nasila się niepewność pomyślności pozyskania zatrudnienia przez nowo promowanych absolwentów, bezpośrednio po ukończeniu studiów wyższych. Proces przechodzenia osób z danego etapu edukacyjnego (zwłaszcza akademickiego) do etapu zatrudnienia nazwany został tranzycją (Allen, Velden, 2007) $)^{1}$.

Tempo i charakter tranzycji uzależnione są od wielu czynników, w tym głównie od poziomu i kondycji gospodarki, różnic społeczno-kulturowych oraz systemowych, zwłaszcza systemów kształcenia. Niepowodzenie tego procesu rodzi szereg negatywnych konsekwencji społecznych, psychologicznych i ekonomicznych.

\section{CEL, ZAKRES OPRACOWANIA}

Mimo doniosłości problemu przechodzenia przez nowo promowanych absolwentów szkół wyższych z etapu edukacji do etapu zatrudnienia proces ten jest jednym z najsłabiej zbadanych zjawisk zachodzących na rynku pracy, zarówno w ujęciu teoretycznym, jak i empirycznym. Kluczowymi przyczynami tego stanu są dopiero rodząca się w koncepcji edukacji akademickiej idea optymalizacji zatrudnialności absolwentów oraz brak cyklicznych, ogólnokrajowych monitoringów diagnozujących losy zawodowe tej populacji.

Pierwsze teorie rynku pracy, wskazujące wybrane determinanty tranzycji absolwentów szczebla kształcenia wyższego, sformułowano w latach 60. i 70. XX wieku. Chronologicznie najwcześniej teorie przechodzenia ze szkoły do pracy powstały w naukach ekonomicznych i socjologicznych, np.: teorie kapitału ludzkiego (Becker, 1964); filtra (Arrow, 1973) czy sygnalizacyjna (Spence, 1973). Teorie te, oprócz poziomu wykształcenia, ogniskowały się wokół wpływu innych czynników, mogących warunkować integrację absolwentów na rynku pracy. Były to osobowość i zachowania podmiotu, aspekt adaptacji, braku luk w życiorysie zawodowym i jego jakości jako jednego z kryteriów rekrutacji; produktywność demonstrowana przez kandydata; dodatkowe kryteria naboru do pracy; łatwość dostosowania się do zmiennych warunków (Rożnowski, 2009).

Zagadnienie tranzycji staje się obecnie przedmiotem zainteresowania specjalistów z różnych dyscyplin naukowych, czego następstwem jest wielość ujęć badawczych, mnogość metod badawczych stosowanych do eksploracji tej problematyki. W sytuacji tak dużej eklektyczności w zakresie opisu procesów tranzycji zachodzi potrzeba analizy teorii wchodzenia na rynek pracy, powstałych w ramach różnych dyscyplin naukowych, zwłaszcza w ekonomii,

1 „Tranzycja” to termin polisemiczny, wywodzący się od angielskiego słowa transition i w kontekście rynku pracy odnosi się do ,przejścia z świata edukacji do pracy, polegającego na zmianach o charakterze socjoekonomicznym, odbywającego się głównie w wieku 15-24 lat, kiedy jednostki w sposób nasilony rozwijają swoje umiejętności, które mają powodować, iż staną się one produktywnym członkiem społeczeństwa" (www.worldbank.org, dostęp 9.11.2013). 
socjologii i psychologii. Przestudiowanie naukowych teorii rynku pracy przedstawiających mechanizmy tego przejścia jest niezbędne do stworzenia teoretycznych podstaw badania procesu wchodzenia nowo promowanych absolwentów na rynek pracy. Dlatego głównym celem opracowania jest przedstawienie wybranych teorii rynku pracy/ wchodzenia na rynek pracy, które są szczególnie istotne w odniesieniu do absolwentów szkół wyższych i w świetle literatury poświęconej tym teoriom mają kluczowe znaczenie w procesach tranzycji zachodzących w gospodarkach opartych na wiedzy. Ponadto celem artykułu jest dokonanie analizy ewolucji teorii rynku stosowanych w modelach tranzycji absolwentów szkół wyższych.

Wybrane cele badań i kryteria selekcji skutkowały wyborem kilkunastu teorii do ich dalszej pogłębionej analizy w niniejszej pracy. Są to, w porządku alfabetycznym, teorie: aspiracji, determinacji, filtra, kapitału ludzkiego, kapitału psychologicznego, kapitału społecznego, kompetencji, konkurencji, motywacji, sygnałów (sygnalizacyjnej), segmentacji.

\section{TEORIE RYNKU PRACY/ WCHODZENIA NA RYNEK PRACY}

W naukach ekonomicznych, ze względu na eksponowane w nich hipotezy, wyodrębnia się trzy grupy teorii. W pierwszej z nich uwypuklany jest aspekt czynnika czasu w procesach dostosowawczych, zachodzących na rynku pracy, a zjawisko bezrobocia czy wakujących miejsc pracy wyjaśniane jest opóźnieniem pomiędzy podażą a popytem. Do nurtu tego zalicza się m.in. teorie: kapitału ludzkiego, konkurencji, naturalnej stopy bezrobocia (NRU), sygnalizacyjną/sygnałów. W grupie drugiej podkreślona została rola płacy, a nadwyżka podaży nad popytem jest uznawana za następstwo niskiej elastyczności płac. Takie ujęcie prezentują m.in. teorie: płacy efektywnej, insiders-outsiders, kontraktu oraz pracy wydajnościowej. Ostatnia grupa teorii ogniskuje uwagę na wpływie czynników strukturalnych i instytucjonalnych jako tych, które decydują o podaży i popycie na pracę. Hipotezy te znajdują odzwierciedlenie m.in. w koncepcjach segmentacyjnych (Dybała 2010; Jarmołowicz, Knapińska 2011). Proces wchodzenia na rynek pracy świeżo promowanych absolwentów w warunkach gospodarki opartej na wiedzy obrazują teorie: kapitału ludzkiego, filtra, segmentacji, sygnalizacyjna i konkurencji.

Według teorii kapitału ludzkiego możliwości znalezienia zatrudnienia oraz warunki pracy (dochód) są uzależnione od poziomu inwestycji pracobiorcy we własny rozwój. Popyt na pracę, jako czynnik wpływający na bezrobocie, odgrywa w tej teorii marginalną rolę. Głównym założeniem teorii kapitału ludzkiego jest więc permanentne rozwijanie swoich umiejętności, zdobywanie wykształcenia, co czyni pracobiorców atrakcyjnymi dla pracodawców i pozwala im korzystnie sprzedać swoje zasoby na rynku pracy. Inwestycja w kapitał ludzki nie gwarantuje sukcesu i jest obarczona pewnym ryzykiem, ale w zdecydowanym stopniu przyczynia się do lepszego startu na rynku pracy, zwłaszcza gdy jest to rynek oparty na zasobach wiedzy (Becker, 1964).

Drogi budowania kapitału ludzkiego są dwojakie: formalna i nieformalna. Wyraźnie podkreślono znaczenie edukacji formalnej (szkolnej/akademickiej), uzupełnianej podejmo- 
waniem doskonalenia, dokształcania pozaszkolnego/pozaakademickiego. Kapitał jest tym bogatszy, im wyższy etap kształcenia ukończyła dana osoba. Podkreśla się wpływ edukacji na pomyślność wejścia na ten rynek, zwłaszcza w odniesieniu do nowo promowanych absolwentów uczelni wyższych (Brzinsky-Fay, 2011).

Ścieżka nieformalna oznacza głównie kształcenie praktyczne w toku wykonywania pracy (learning by doing). Istotna jest także rola wrodzonych zdolności, w tym zwłaszcza gotowość do dużego wysiłku i pracowitość. Takie dwutorowe działania edukacyjne, osadzone na cechach wrodzonych podmiotu, zapewniają akumulację kapitału ludzkiego ogólnego i specyficznego. G.S. Becker zauważył, że pracobiorcy wykazują wyższe zainteresowanie kapitałem specyficznym, który odpowiada ich bieżącym potrzebom, podczas gdy pracobiorcy skupiają się na zgromadzeniu jak najbardziej zaawansowanego kapitału ogólnego (Figurska, 2009). Kapitał specyficzny, nazywany też specjalistycznym, ma w gospodarkach opartych na wiedzy szczególnie duży wpływ na pozycję absolwentów na rynku pracy. Ten dysonans może być przyczyną zakłóceń tranzycyjnych wśród absolwentów szkół wyższych.

Inwestycje w budowanie kapitału ludzkiego dywersyfikują siłę roboczą na różne kategorie jakościowe. Dlatego kapitał ten jawi się nie tylko jako czynnik ułatwiający poruszanie się na rynku pracy, ale i jako faktor, który wyznacza granice tego ruchu. Z tym założeniem w sposób ścisły powiązana jest teoria filtra, która stawia hipotezę o nierówności pozycji i szans ludzi na rynku, uzależnionej od jakości kapitału ludzkiego, jaki udało im się zgromadzić do czasu rozpoczęcia poszukiwań zatrudnienia. Wartość kapitału jest swoistym sitem/ filtrem rozdzielającym podmioty na te, które dysponując bardzo dużym kapitałem ludzkim, są poszukiwane i lepiej opłacane przez pracodawców, oraz na te, które posiadają relatywnie mniejszy kapitał ludzki, spotykają się z dużo mniejszym zainteresowaniem pracodawców i mogą spodziewać się mniej atrakcyjnych warunków zatrudnienia. Wyższe wykształcenie w teorii filtra jest podstawowym predyktorem pozycji na rynku pracy i motorem napędzającym koniunkturę rynku edukacji akademickiej (Arrow, 1973).

Wskazanie poziomu wykształcenia jako czynnika podziału na rynku pracy jeszcze mocniej wyraża teoria segmentacji, która obejmuje dwie kluczowe hipotezy, tj., że rynek jest heterogeniczny i składa się z obszarów, które cechują różne warunki proponowane pracownikom w zakresie płac i polityki zatrudnienia oraz że wejście na dane obszary - segmenty - jest do pewnego stopnia ograniczone. Segmenty te dzielą się na pierwotne i wtórne. Segment pierwotny oferuje stabilne, wyżej opłacane, bardziej prestiżowe i dające wyższe szanse awansu miejsca pracy. Segment wtórny dysponuje miejscami pracy niżej opłacanymi, o mniejszym prestiżu i perspektywach rozwoju zawodowego (Jarmołowicz, Knapińska, 2011). Brak swobody przepływu między nimi powoduje permanentny stan nierównowagi. Akces do segmentu pierwotnego mają osoby najlepiej wykształcone, a wśród nich tylko takie, które w gospodarce opartej na wiedzy mają kompetencje potrzebne do świadczenia najwyższej jakości usług, produkcji zaawansowanych technologiczne towarów itd. ${ }^{2}$ Zdaniem E. Kryńskiej z zasady absolwenci każdego poziomu edukacji wchodzą na rynek wtórny, a nie pierwotny. W segmencie wtórnym, o mniej atrakcyjnych warunkach pracy (wymiernych jak

${ }^{2}$ Segmenty mogą być także wyodrębniane przestrzennie (lokalne, regionalne rynki pracy), gdzie to przestrzeń działa jak bariera mobilności, a poziom mobilności między nimi wyznaczają koszty dojazdów. 
płace i niewymiernych jak atrakcyjność zadań do realizacji), panuje największa konkurencja. Wzmocnienie wiedzy akademickiej doświadczeniem zdobytym w pracy na tym rynku stwarza największą szansę na ewentualne przejście do segmentu pierwotnego (Kryńska, 1998). Zbyt długie pozostawanie absolwentów szkół wyższych w sferze rynku wtórnego może mieć wielorakie negatywne konsekwencje. Zalicza się do nich zwłaszcza: całkowitą lub częściową utratę umiejętności nabytych w trakcie studiów, niższą efektywność pracy wynikającą z poczucia frustracji i rozczarowania, trwałą obawę przed poszukiwaniem zatrudnienia i niższą intensywność jego poszukiwania (Wolbers, 2007).

Kolejną teorią wskazującą poziom wykształcenia jako determinantę wchodzenia/ poruszania się na rynku pracy jest teoria sygnalizacyjna (sygnałów) (signalling theory). Opiera się ona na presumpcji, że kluczowym czynnikiem przyczyniającym się do pozyskania pracy jest legitymowanie się dyplomami i innymi certyfikatami, które potwierdzają poziom kompetencji pracobiorcy, zapowiadają prawdopodobnie jego wysoką produktywność. Na rynku pracy widoczna jest asymetria informacji między pracobiorcami i pracodawcami. Ci pierwsi znają swoje walory i umiejętności, a pracodawcy tej wiedzy nie mają, bo nie obserwują czynnie procesu kształcenia. Mogą oni jedynie spodziewać się poziomu umiejętności na podstawie jakości dyplomu, liczby lat edukacji i zakładać, że im osoba dłużej się uczyła, tym więcej umiejętności nabyła i rokuje nadzieję na większą wydajność w pracy. Edukacja stanowi więc formalny test zasobów intelektualnych osoby poszukującej pracy, który służy wysłaniu sygnału potencjalnemu pracodawcy o jej relatywnie wysokiej produktywności (Spence, 1973).

Założenia teorii sygnalizacyjnej były częściowo weryfikowane empirycznie i ulegały ewolucji. Potwierdzono wertykalną zależność między poziomem wykształcenia a pozycją na rynku pracy. Za zasadniczy profit płynący z zatrudnienia osób legitymujących się wykształceniem akademickim pracodawcy wskazali potrzebę niższych nakładów finansowych na przeszkolenie takich pracowników, bo znacznie szybciej opanowywali oni zakres potrzebnej wiedzy i umiejętności niż ich konkurenci z wykształceniem średnim czy zawodowym. Dostrzegli także korzyści będące następstwem tzw. unobservable characteristics, czyli cech jakościowych/niewidocznych, takich jak większa elastyczność, zdolność do szybkiej adaptacji, a nawet lepszy stan zdrowia tych pracowników. Wreszcie istotna jest też większa transferowalność umiejętności wypracowanych na szczeblu kształcenia akademickiego i większe prawdopodobieństwo wykorzystania ich w wielorakich działaniach i na różnych stanowiskach pracy (Weiss, 1995).

Obecnie dynamiczny wzrost liczby absolwentów z dyplomem studiów wyższych powoduje, że poziom wykształcenia traci swój potencjał sygnalizacyjny i funkcję tę pełnią: stopień, tryb ukończonych studiów, marka uczelni. Po wyselekcjonowaniu grupy potencjalnych pracowników na podstawie wskazanych parametrów wiodącą rolę sygnalizacyjną w dalszym postępowaniu rekrutacyjnym odgrywa kierunek studiów wyższych. Badania empiryczne potwierdzają znaczny wpływ sygnału „wysyłanego” już nie przez szczebel kształcenia, ale przez kierunek ukończonych studiów. Na przykład w Niemczech jednoznacznie płynniejszą i satysfakcjonującą tranzycję przechodzą absolwenci wysoko specjalistycznych (wąskich) kierunków studiów, którzy oferują pracodawcom rzadko spotykane umiejętności (Klein, 2010). 
Aspekt wpływu poziomu wykształcenia na przebieg poszukiwania pracy bezpośrednio po zakończeniu edukacji w ujęciu spodziewanych kosztów pełnego przeszkolenia pracownika do realizacji zadań na określonym stanowisku rozważany jest w teorii konkurencji (the job-competition theory). Teorię tę oparto na hipotezie, że absolwent rzadko jest w pełni gotowy do wykonywania konkretnych zadań w miejscu pracy, dlatego nieuniknione jest jego przeszkolenie. Pracodawcy poszukują pracowników, którzy najszybciej i najtaniej mogą zostać przez nich przygotowani do wykonywania zadań. Podobnie jak w teorii sygnałów poziom wykształcenia jest ważną przesłanką dla pracodawcy o prawdopodobnie najszybszym i najmniej kosztownym procesie adaptacji kandydata do wykonywania określonych zadań. Twórcy opisywanej teorii uznają, że osoby poszukujące pracy tworzą swoistą kolejkę i rywalizują między sobą o miejsce w tym szeregu, a zasadniczym narzędziem konkurencji jest posiadany przez nie poziom wykształcenia (Thurow, 1979).

Rolę jakości edukacji wyższej w procesie wchodzenia na rynek pracy uczyniono wiodącą w teorii kompetencji. Teoria ta zakłada ścisłą zależność między ilością i jakością (różnorodnością, poziomem opanowania) kompetencji, które posiada dany absolwent a tempem pozyskania przez niego zatrudnienia i stopniem zgodności pracy z poziomem ukończonej edukacji oraz profilem studiów.

Należy zaznaczyć, że w rozważaniach o rynku pracy współwystępują dwa sposoby rozumienia kompetencji, które w języku angielskim są odzwierciedlone za pomocą słów competency i competence. Pierwszy termin wywodzi się ze Stanów Zjednoczonych, gdzie kompetencja ma podłoże behawioralne i jest ujmowana jako sposób zachowania, który wpływa na powodzenie wykonywanych w pracy zadań (Strzebońska, Dobrzyńska, 2011). W tym rozumieniu kompetencje zbudowane są zazwyczaj ze składowych wiedzy, umiejętności i postaw. Termin competence powstał na gruncie brytyjskim i dotyczy wystandaryzowanych rezultatów/wyników wykonywanych działań, przypisanych do zawodu czy stanowiska pracy. Przy tym procedurze standaryzacji podlegają nie zachowania prowadzące do realizacji celu, ale skutki tych działań. Wymagane jest, aby wiedza, umiejętności i postawy wchodzące w zakres danej kompetencji były uszczegółowione na podstawie ustalonych i powszechnie dostępnych kryteriów, np. efekty kształcenia przyjęte w Europejskich i Krajowych (polskich) Ramach Kwalifikacji (Mikuła, Pietruszka-Ortyl, 2007).

Pierwszych empirycznych weryfikacji tej teorii, ustalających relację między nabytymi na studiach umiejętnościami a stosowaniem ich w pracy zawodowej dokonano w Stanach Zjednoczonych w latach 30. XX wieku. Opracowania mające na celu ukazanie kompetencji absolwenckich jako determinanty sukcesu zawodowego rozpoczęto w roku 1973, także w USA (Bielecki, 2011). Początkowo nie podejmowano się określenia roli kompetencji w pozyskaniu pracy. W następnych latach wśród badaczy europejskich i amerykańskich wykrystalizował się pogląd, że to właśnie kompetencje absolwenckie powinny być pierwszoplanowym przedmiotem badań i standardem przy planowaniu i realizacji procesu kształcenia na poziomie wyższym. Stwierdza się, że uczelnie, które troszczą się o przyszłość swoich studentów na rynku pracy, powinny kształtować u nich zarówno kompetencje specyficzne, blisko powiązane z danym kierunkiem studiów, jak i kompetencje transferowalne, zwane także kluczowymi lub ogólnopracowniczymi (Jeruszka, 2011). Biegłość w zakresie tych 
kompetencji jest podstawą wysokiego stopnia adaptacyjności do pracy na różnych stanowiskach. Takie spojrzenie na istotę kompetencji w procesie tranzycji nowo promowanych absolwentów szkół wyższych przyjęto w badaniach o skali europejskiej (badania projektu HEGESCO).

Należy też podkreślić, iż na dzisiejszym, wymagającym rynku pracy, kompetencje uniwersalne powinny być coraz bardziej rozszerzane o tzw. kompetencje wyróżniające (Strużyna, 1999). Stanowią one szczególnie cenny kapitał, jeżeli zostaną wykształcone na najwyższym poziomie i będą właściwie prezentowane oraz odświeżane przez absolwentów. To permanentne pogłębianie, aktualizowanie kompetencji jest warunkiem pozyskania i utrzymania pracy w gospodarce opartej na wiedzy.

Przedstawione dotychczas teorie majoryzują rolę samego pracobiorcy - absolwenta szkoły wyższej - w zapewnieniu sobie satysfakcjonującego wejścia na rynek pracy. To od indywidualnych trafnych decyzji co do wyboru dróg budowania swojego kapitału, złożonego z poziomu edukacji formalnej, nieformalnej, marki uczelni, wyboru kierunku studiów, wreszcie własnego zaangażowania w opanowanie pożądanych kompetencji niemal wyłącznie zależy jego los na rynku pracy. Nieco inaczej czynniki warunkujące pomyślność tranzycji ujmuje teoria kapitału społecznego, która jest osadzona na socjologicznym definiowaniu rynku pracy jako instytucji życia społecznego obejmującej kanony ludzkich zachowań, gdzie dochodzi do spotkania wolnych i suwerennych w swoich decyzjach pracodawców i pracobiorców. Uwaga socjologów skupia się na jednostce poszukującej pracy jako na osobowości każdorazowo wyposażonej w inny zestaw cech, które mają różne pochodzenie (Czyszkiewicz, Durka, Klepajczuk, 2007). Tempo i charakter wejścia na rynek pracy są zależne od sieci społecznych powiązań podmiotu, które budują jego niewymierny (jakościowy) kapitał, zwłaszcza zapewniają mu nieformalne informacje o potencjalnie wolnych miejscach pracy. W teorii tej dostęp do tych danych nie jest więc jednakowy dla wszystkich osób poszukujących zatrudnienia, ale zależy od tak zwanego kapitału społecznego, pozwalającego na uruchomienie w procesie poszukiwania zatrudnienia więzi rodzinnych, towarzyskich, sąsiedzkich, rówieśniczych i wcześniejszych kontaktów zawodowych. Jakość kapitału społecznego odzwierciedla się w strukturze tak zwanej sieci 3F (families, friends, firms), tj.: rodzina, znajomi, firmy. Te trzy źródła są rozumiane jako swoisty serwis informacyjny i doradczy, będący konsekwencją odmiennych dla każdej osoby zasobów, tkwiących w relacjach rodzinnych, koleżeńskich, które mogą wspomagać jednostki w osiąganiu stawianych sobie celów, w tym w pozyskaniu pracy. W takim ujęciu wymienione kontakty stanowią niejako dodatkową bazę danych, dostępną dla wybranych osób i mogą stanowić wsparcie w trakcie przygotowań do rozmów o pracę czy też być źródłem referencji (pisemnych, ustnych), świadczących na korzyść osoby poszukującej pracy. Wyższe wykształcenie własne przede wszystkim powiększa szanse na zbudowanie silnej grupy poziomu drugiego (sieć koleżeńska, zawodowa) i tym samym może przyczyniać się do sprawniejszej tranzycji. Badania wykazały, że kluczowy wpływ na pomyślne wejście absolwentów na rynek pracy ma poziom wykształcenia rodziców (zwłaszcza matki), kolejno rodziny, kolegów i sąsiadów. Na przykład: jeśli jedno z rodziców absolwenta ma taki sam poziom wykształcenia i zbliżony do niego kierunek skończonych studiów, to może szybciej przekazywać mu wiedzę na 
temat strategii pozyskania pracy w branży typowej dla osób z takim profilem wykształcenia lub mieć łatwiejszy dostęp do informacji o naborze do pracy. Podobny mechanizm dotyczy wcześniejszych relacji zawodowych i koleżeńskich (Ben-Portah, 1980; Caliendo, Schmidl, Uhlendorff, 2010).

Kapitał ten bywa także określany jako zasięgi powiązań, różniące się intensywnością relacji i nazywane są siecią $\mathbf{3 B}$ (binding, bonding, belonging), tj.: sfera najbliższa (powiązania ścisłe/rodzinne, kontakty bardzo częste); bliska (relacje towarzyskie, częste); strefa przynależności/identyfikacji (do danej grupy zawodowej, społecznej, kontakty luźne i rzadkie). Poziom wykształcenia warunkuje skalę zasięgów tych powiązań i tym samym wpływa na sytuację absolwenta na rynku pracy.

Pierwszy pierścień relacji uznawany jest za najbardziej efektywny z dwóch powodów: silnie emocjonalnego związku między elementami zbioru oraz dużej dywersyfikacji źródeł wiedzy o potencjalnym miejscu pracy. Tworzą go bowiem osoby w różnym wieku, o różnym profilu wykształcenia i wykonywanego zawodu. Gdy to pole jest bogate, nie trzeba sięgać do pozostałych, aby pozyskać pracę. W drugiej sferze mogą, ale nie muszą występować silne powiązania między osobami (przyjaźń, koleżeństwo o różnym stopniu zaangażowania w relację). Grupa koleżeńska najczęściej powstaje w trakcie wspólnej edukacji, jest zatem mniej heterogeniczna, a zakres informacji o możliwościach zatrudnienia jest węższy, bo dotyczy osób o zbliżonych zainteresowaniach. Często członkowie tej sfery sami mają podobne dążenia, cele, i wiedzę o ewentualnym naborze do pracy najpierw zagospodarują dla siebie, następnie przekażą ją członkom swoich rodzin, a dopiero potem podzielą się nią z rówieśnikami. Trzeci krąg powiązań jest najluźniejszy, ale też podnosi prawdopodobieństwo pozyskania informacji o miejscu pracy i może być np.: źródłem sprzyjających rekomendacji (Lin, 2005).

Inne spojrzenie na mechanizmy kształtujące proces wchodzenia na rynek pracy prezentowane jest w teoriach socjologiczno-psychologicznych i psychologicznych. Tu sfera osobowości, emocji, pragnień, aspiracji, predyspozycji psychologicznych absolwenta uznawana jest za czynnik decydujący o tempie i charakterze tranzycji. I tak, według teorii kapitału psychologicznego (psychological capability), skuteczność w pozyskaniu pracy może zostać zdeterminowana przez cztery najważniejsze obszary: wiarę w siebie/pewność siebie rozumianą jako przekonanie o zdolności sprostania zróżnicowanym wymaganiom i trudnym zadaniom; optymizm; nadzieję, czyniącą możliwym realizację celów oraz upór i elastyczność, która pozwala dążyć do celu. Im więcej z wymienionych zakresów charakteryzuje dany podmiot, tym bardziej rośnie jego szansa na powodzenie na rynku pracy. Komponent wszystkich wyżej wymienionych aspektów zapewnia sukces tranzycyjny i jest kluczowy nie tylko w procesie poszukiwania pracy, ale i przy jej wykonywaniu. Przynajmniej jeden z filarów kapitału psychologicznego, tj.: wiara w siebie i wysoka samoocena, rozwija się w dużej mierze w procesie edukacyjnym i powinien być relatywnie najwyższy u osób z legitymujących się dyplomem akademickim (Luthans, Youssef, Avolio, 2006).

Psychologowie wyprowadzili z tych rozważań kolejne teorie, tj.: teorię oczekiwań (expectancy-value theory), zwaną także teorią aspiracji, oraz teorię motywacji, określaną również jako teorię determinacji (determination theory). 
Czynnikiem silnie różnicującym plany życiowe, doraźne i perspektywiczne zamierzenia, są indywidualne aspiracje. W psychologii i socjologii stosuje się różne definicje pojęcia aspiracji, ale najczęściej opisywane są one jako pragnienia, życzenia i dążenia, zamiar osiągnięcia celu oraz cel działań. W kontekście tranzycji przedmiotem aspiracji są określone wartości oraz pragnienia, dotyczące przyszłości zawodowej i osobistej. W hierarchii celów życiowych absolwentów legitymujących się wyższym wykształceniem jedno z pierwszych miejsc zajmuje pozyskanie pracy satysfakcjonującej merytorycznie i finansowo. Aspiracje wyznaczają kierunki działania podmiotu, jego aktywność w realizacji i tym samym, możliwości osiągnięcia zamierzonych celów. Poziom aspiracji jest uzależniony w dużej mierze od szczebla ukończonej edukacji i jest na ogół najwyższy w przypadku osób z dyplomem uczelni wyższej. W teorii aspiracji zakłada się, że osoba z wysokimi oczekiwaniami będzie poszukiwała zatrudnienia z większą determinacją i intensywnością, bo dla niej głównym celem jest nie tylko zdobycie pracy, ale i potrzeba samorealizacji (Piróg, 2012; Sikorski, 2005).

W teorii motywacji to właśnie motywacja jest osią działań podmiotu w drodze do zrealizowania celów życiowych, do których zalicza się zdobycie atrakcyjnej pracy. Wyróżniono dwa typy motywacji: wewnętrzną, zwaną także swobodną lub autonomiczną, i zewnętrzną (kontrolowaną). Motywacja swobodna dotyczy poczucia winy, wstydu, uchylania się od zadań/powinności, satysfakcji i zadowolenia, wypływa z woli i wyboru, jest konsekwencją osobistych/wewnętrznych potrzeb podmiotu. Motywacja zewnętrzna wynika często z oddziaływania grupy, w której funkcjonujemy, lub presji czynników zewnętrznych, wpływu bliskich osób (rodziny) czy chęci „dopasowania” się do określonej grupy społecznej. Motywacja zewnętrzna przejawia się zatem poszukiwaniem aprobaty, chęcią bycia postrzeganym jako osoba pracowita, zaradna, lub wynika z chęci uniknięcia kary. Badania pokazały, że poziom wykształcenia sprzyja budowaniu i ugruntowywaniu motywacji wewnętrznej, a ta okazuje się (w toku badań empirycznych), najskuteczniejszą w procesie pozyskiwania satysfakcjonującej pracy (Vansteenkiste i in., 2005; Vansteenkiste, Lens, Deci, 2006).

\section{PODSUMOWANIE: EWOLUCJA TEORII RYNKU STOSOWANYCH W MODELACH} TRANZYCJI ABSOLWENTÓW SZKÓŁ WYŻSZYCH

Przedstawione teorie stanowią podwaliny naukowych badań mechanizmów procesu tranzycji w odniesieniu do absolwentów szkół wyższych. Żadna teoria rynku pracy nie jest na tyle ogólna, by mogła mieć zastosowanie w każdym czasie, systemie gospodarczym i regionie, dlatego w budowaniu modeli przechodzenia na rynek pracy odnoszono się na ogół do założeń kilku z nich jednocześnie. Nasilające się problemy płynnego wejścia absolwentów studiów wyższych na rynek pracy zaowocowały ewolucją wypracowywanych modeli tranzycji, w których nawiązywano (z różną intensywnością) do scharakteryzowanych teorii.

W latach 90. XX wieku zakładano, że sukces wejścia na rynek pracy po ukończeniu studiów jest rezultatem oddziaływania trzech równoważnych czynników: kondycji rynku pracy oraz poziomu innowacyjności gospodarki, czynników indywidualnych i zgromadzonego 
kapitału ludzkiego. W budowaniu tego modelu uwzględniono i uznano za istotne w równym stopniu założenia teorii kapitału ludzkiego, sygnałów, kapitału społecznego oraz aspiracji. Kapitał ludzki budują w nim: system, kierunek i program studiów, zaplecze kadrowe i naukowo-badawcze ukończonej przez absolwenta uczelni oraz jego zaangażowanie, zarówno w proces samokształcenia formalnego, jak i nieformalnego. Komponenty kapitału edukacyjnego zostały wówczas potraktowane, zgodnie z teorią sygnałów, jako atuty pracobiorcy, które są ważnym elementem rekrutacji. Wskazano wpływ pochodzenia społecznego i wykształcenia rodziców absolwenta oraz charakter jego aspiracji/oczekiwań. Wszystkie te czynniki oddziałują z różnym nasileniem, w zależności od lokalnych uwarunkowań (Teichler, 1997).

Od początku XXI wieku można obserwować tendencję do budowania modeli tranzycji, głównie z wykorzystaniem założeń teorii kapitału ludzkiego i majoryzowaniem roli poziomu oraz jakości zdobytego wykształcenia. Stosuje się pojęcie kapitału edukacyjnego, który obejmuje filozofię danej uczelni, przejawiającą się m.in. w jej stosunku do sytuacji swoich absolwentów na rynku pracy, wizji sylwetki absolwenta, polityce współpracy z pracodawcami, realizacji procesu kształcenia i w skuteczności działań biur karier. Specyfika misji uczelni wyższej i jakość jej wdrażania w życie przekłada się na indywidualne działania studentów i absolwentów, zwłaszcza ich dążenia do osiągania jak najlepszych efektów kształcenia, zdobywania dodatkowych kwalifikacji, doświadczeń zawodowych na rynku pracy i wreszcie zaangażowania w proces poszukiwania pracy (Harvey, Locke, Morey, 2002).

Najnowsze modele przechodzenia absolwentów uczelni wyższych odwołują się głównie do teorii kompetencji i teorii kapitału ludzkiego. Dysponowanie szerokimi kompetencjami, zdolność ich transferu do potencjalnego miejsca pracy i szybkiego dopasowania do potrzeb pracodawcy jest rezultatem jakości zakończonej edukacji akademickiej. Ta z kolei wynika z trybu, stopnia, kierunku studiów, oceny zamieszczonej na dyplomie, aktywności studenta w kołach naukowych i innych organizacjach studenckich, dodatkowych kursów, szkoleń odbytych $\mathrm{w}$ toku studiowania, staży zagranicznych, wymian międzynarodowych i wszelkich umiejętności, nabytych podczas wykonywania pracy w trakcie studiów. Pełny zakres doświadczeń oraz kompetencji nosi nazwę kapitału tranzycyjnego, który przesądza o sytuacji absolwenta na rynku pracy (Pavlin, 2011).

Na podstawie przeprowadzonych analiz literatury przedmiotu należy stwierdzić, że w gospodarce opartej na wiedzy, rosną wymagania stawiane osobom wchodzącym na rynek pracy. Wspólnym mianownikiem większości przeanalizowanych teorii i modeli są:

- eksternizacja, czyli przesuwanie niemal pełnej odpowiedzialności za jakość przejścia z etapu edukacji do zatrudnienia, na absolwenta danego etapu kształcenia (Bańka, 2005);

- uwypuklanie zależności statusu podmiotu na rynku pracy od ukończonego szczebla edukacji;

- podkreślanie konieczności dysponowania przez absolwenta rozległym zasobem kompetencji, które warunkują zarówno wykonywanie zadań typowych dla zdobytego wykształcenia (kierunku studiów), zdolność do sprawnej adaptacji w miejscu pracy, jak i szybkie przekwalifikowanie się; 
- wskazywanie na konieczność bardzo aktywnego wykorzystania okresu studiów wyższych do zgromadzenia licznych doświadczeń akademickich, naukowych i zawodowych, które budują kapitał tranzycyjny absolwenta.

\section{Literatura}

Allen, J., Velden Van der, R. (2007). Transitions from Higher Education. W: U. Teichler (ed.), Careers of University Graduates. Dodrecht: Springer, 55-78.

Arrow, K.J. (1973). Higher Education as a Filter. Journal of Public Economics, 2, 193-216.

Bańka, A. (2005). Transnacjonalne poradnictwo zawodowe w kontekście zmian w wymiarze europejskim. W: M. Kwiatkowski, Z. Sirojc (red.), Edukacja dla rynku pracy. Problemy poradnictwa zawodowego. Warszawa: Wydawnictwo OHP, 35-48.

Becker, G.S. (1964). Human Capital: A Theoretical and Empirical Analysis, With Special Reference to Education. Chicago: University of Chicago Press.

Ben-Porath, Y. (1980). The F-connection: Families, Friends, Firms, the Organization of Exchange. Population and Development Review, 6, 1-9.

Bielecki, P. (2011). Kompetencje absolwentów studiów wyższych w świetle ogólnoeuropejskich badań CHEERS, REFLEX i TUNNG. W: K. Jędralska, K. Bernais (red.), Kompetencje absolwentów studiów ekonomicznych. Perspektywa nauki i biznesu. Katowice: Wydawnictwo Uniwersytetu Ekonomicznego w Katowicach, 13-66.

Borowiec, M. (2008). Rola szkolnictwa wyższego w procesie kształtowania gospodarki opartej na wiedzy. Przedsiębiorczość - Edukacja, 4, 24-36.

Brzinsky-Fay, Ch. (2011). School - to - Work Transitions in International Comparison. Acta Electronica Universitatis Tamerensis, 1126, 213.

Caliendo, M., Schmidl, R., Uhlendorff, A. (2010). Social Networks, Job Search Methods and Reservation Wages: Evidence for Germany. Discussion paper series / Forschungsinstitut zur Zukunft der Arbeit, 5165, 30.

Chojnicki, T. Czyż, T. (2003). Polska na ścieżce rozwoju gospodarki opartej na wiedzy. Podejście regionalne. W: A. Kukliński (red.), Gospodarka oparta na wiedzy. Perspektywy Banku Światowego. Warszawa: KBN.

Czyszkiewicz, R., Durka, W., Klepajczuk, B. (2007). Podmioty polskiego rynku pracy - interpretacje socjologiczne. Studia Socjologica 17. Zeszyty Naukowe Uniwersytetu Szczecińskiego, 484, 25-40.

Dybała, A. (2010). Rynek pracy w wybranych teoriach ekonomii. W: A. Dybała (red.), Rynek pracyteoria i realia. Wyniki z badań $i$ analiz dla miasta Kielce. Kielce: Wydawnictwo Uniwersytetu Humanistyczno-Przyrodniczego Jana Kochanowskiego w Kielcach, 15-34.

Figurska, I. (2009). Rola wykształcenia w gospodarce opartej na wiedzy. W: T. Szot-Gabryś (red.), Wiedza jako czynnik rozwoju gospodarki $i$ wiedzy. Kielce: Wydawnictwo Wyższej Szkoły Umiejętności im. S. Staszica.

Harvey, L., Locke, W., Morey, A. (2002). Enhancing Employability, Recognizing Diversity. Making Links between Higher Education and the World of Work. London: Universities, UK.

Jarmołowicz, W., Knapińska, M. (2011). Współczesne teorie rynku pracy a mobilność i przepływy pracowników w dobie globalizacji. Zeszyty Naukowe Uniwersytetu Ekonomicznego w Poznaniu, 9, 123-144. 
Jeruszka, U. (2011). Efektywność kształcenia w szkołach wyższych. Polityka Społeczna, 1, 1-7.

Kabaj, M. (2001). Rozwój i wykorzystanie zasobów pracy - w kierunku gospodarki opartej na wiedzy. W: A. Kukliński (red.), Gospodarka oparta na wiedzy. Wyzwanie dla Polski XXI wieku. Warszawa: KBN, 165-202.

Klein, M. (2010). Mechanisms for the Effect of Field of Study on the Transition from Higher Education to Work. Working Papers, 130, 30.

Kryńska, E. (1998). Wybrane teorie rynku pracy a prognozowanie. W: E. Kryńska, J. Suchecka, B. Suchecki (red.), Prognoza podaży i popytu na prace w Polsce do roku 2010. Studia i Materiały. Warszawa: Instytut Pracy i Spraw Socjalnych.

Kukliński, A. (red.) (2001). Gospodarka oparta na wiedzy. Wyzwanie dla Polski XXI wieku. Warszawa: KBN.

Lin, N. (2005). A Network Theory of Social Capital. W: D. Castiglione, J. Deth Van, G. Wolleb (ed.), Handbook on Social Capital. New York: Oxford University Press.

Luthans, F., Youssef, C.M., Avolio, J. (2006). Psychological Capital:Developing the Human Competitive Edge: Developing the Human Competitive Edge. New York: Oxford University Press.

Makulska, D. (2012). Kluczowe czynniki rozwoju w gospodarce opartej na wiedzy. W: J. Stacewicz (red.), Pomiędzy polityka stabilizacyjna a polityka rozwoju, Prace i Materiały Instytutu Rozwoju Gospodarczego SGH, 88. Warszawa: SGH, 169-194.

Mikuła, B., Pietruszka-Ortyl A. (2007). Kompetencje pracowników w perspektywie strategicznego zarządzania wiedzą w przedsiębiorstwie. Zeszyty Naukowe Akademii Ekonomicznej w Krakowie, 747,52 .

Pavlin, S. (2011). Varieties of Professional Domains and Employability Determinants in Higher Education. AlmaLaurea Working Papers, 36, 12-16.

Piróg, D. (2012). Aspiracje i plany zawodowe młodzieży akademickiej w Polsce na przykładzie studentów geografii. W: A. Dudak, K. Klimkowska, A. Różański (red.), Przygotowanie zawodowe młodych pedagogów. Kraków: Oficyna Wydawnicza Impuls, 125-144.

Rożnowski, B. (2009). Przechodzenie młodzieży z systemu edukacji na rynek pracy w Polsce. Analiza kluczowych pojęć dotyczacych rynku pracy u młodzieży. Lublin: Wydawnictwo KUL.

Sikorski, W. (2005). Aspiracje. Studium psychologiczne i socjologiczne. Nysa: Wydawnictwo PZWS.

Spence, M. (1973). Job Market Signalling. The Quarterly Journal of Economics, 87(3), 355-374.

Strużyna, J. (1999). Wyzwania pracy XXI wieku. Rynek pracy wobec wyzwań restrukturyzacji. Zeszyty Naukowe WSB, 1(4), 33-34.

Strzebońska, A., Dobrzyńska, M. (2011). Kompetencje jako przejaw kapitału ludzkiego. W: Bilans kapitalu ludzkiego w Polsce. Raport podsumowujacy pierwsza edycję badań realizowana w 2011 roku. Warszawa: PARP, 26-39.

Teichler, U. (1997). Higher Education and Graduate Employment in Europe. TSER Research Paper.

Thurow, L. C. (1979). A Job Competition Model. W: M.J. Piore (ed.), Unemployment and Inflation: Institutionalist and Structuralist Views. White Plains, NY: Sharpe Press, 17-32.

Vansteenkiste, M., Lens, W., De Witte, H., Feather, N.T. (2005). Understanding Unemployment People's Job Search Behaviour, Unemployment Experience and Well-being: A Comparison of Expectancy-Value Theory and Self-determination Theory. British Journal of Social Psychology, 44(2), 269-287.

Vansteenkiste, M., Lens, W., Deci, E. L. (2006). Intrinsic Versus Extrinsic Goal Contents in Self-Determination Theory: Another Look at the Quality of Academic Motivation. Educational Psychologist, 41(1), 19-31. 
Weiss, A. (1995). Human Capital vs. Signalling Explanations of Wages. Journal of Economics Perspectives, 9(4), 133-154.

Wolbers, M.H.J. (2007). Patterns of Labour Market Entry: A Comparative Perspective on School-toWork Transitions in 11 European Countries. Acta Sociologica, 50, 189-210.

Zioło, Z. (2008). Ekonomiczne i społeczne uwarunkowania rozwoju gospodarki opartej na wiedzy. Przedsiębiorczość - Edukacja, 4, 12-23.

Bank Światowy (2013, 9 listopada). Pozyskano z: http://web.worldbank.org/WBSITE/EXTERNAL/ TOPICS /0, contentMDK:21725024 menuPK:4995933 pagePK:148956 piPK:216618 theSitePK: $282386,00 . h t m l$

Danuta Piróg, dr, Uniwersytet Pedagogiczny w Krakowie, Instytut Geografii.

Dr Danuta Piróg jest adiunktem w Instytucie Geografii Uniwersytetu Pedagogicznego w Krakowie. Zainteresowania naukowe D. Piróg ogniskują się wokół dwóch nurtów: zróżnicowania kulturowego Europy i tożsamości jej mieszkańców oraz efektywności studiów geograficznych w aspekcie potrzeb rynku pracy. Obecnie D. Piróg jest kierownikiem projektu badawczego Ministerstwa Nauki i Szkolnictwa Wyższego w zakresie dyscyplin: Polityka Regionalna, Polityka Społeczna i Demografia pt. „Absolwenci studiów geograficznych na rynku pracy w Polsce i wybranych krajach Unii Europejskiej".

Danuta Piróg, PhD, Senior Lecturer at the Pedagogical University of Cracow (Institute of Geography, Department of Didactics). Her research interests are focused on intercultural education, European education, practical preparation of students - candidates for the geography teaching profession and the effectiveness of geographical studies in the context of the needs of the labour market. Currently she is the head of research grant of Ministry of Scientific Research and Information Technology "Graduates of geography studies on the labour market in Poland and in selected European Union countries".

adres/address: Uniwersytet Pedagogiczny w Krakowie

Instytut Geografii

ul. Podchorążych 2, 30-084 Kraków, Polska

e-mail: dbutryn@up.krakow.pl 